\title{
Practice and Discussion on Bilingual Education of Specialized Course-MEMS: A Jiangsu University Case
}

\author{
Daohao Ge, Liqiang Zhang, Fangwei Xie, and Pengfei Qian
}

\begin{abstract}
The bilingual teaching on specialized course has become a trend in most countries and regions in the world with the internationalization of higher education. Especially for China, the bilingual teaching is the inevitable trend of the education internationalization for Chinese universities by the increasing number of exchange students and foreign students in China. It is necessary for teaching reform and personal training in universities. At present, the bilingual teaching of specialized courses is the key and difficult point in the teaching reform of higher education. Some common problems in bilingual teaching of professional courses in Chinese universities and colleges have been analyzed, and some benefit measures are put forward in order to improve the bilingual teaching quality in this paper.
\end{abstract}

Index Terms-Bilingual teaching, specialized courses, reform, international education.

\section{INTRODUCTION}

At present, the educational exchanges between the countries in the world are becoming more and more frequent with the rapid development of economic globalization [1]-[4]. Internationalization is the tendency for higher education, and the bilingual teaching is a prerequisite. Bilingual teaching has become an important pathway to adjust to internationalization for cultivating high-quality personnel, while bilingual teaching model an important means to achieve the teaching goal and process controlling [5]. In order to cultivate the talents with high professional quality and international perspective and the ability to communicate with foreign language, China Ministry of education are put forward that the Chinese undergraduate education should create conditions, and actively promote the use of English and other foreign language courses and professional courses teaching, and bilingual teaching evaluation index as an important course in undergraduate teaching assessment according to the requirements of modern education, the world and the future. Personnel training mode and teaching methods and methods have undergone major changes; bilingual teaching [1]-[10] has gradually become an important part of our higher education in Jiangsu University. As a teacher of bilingual course, the author puts forward some solutions to the

Manuscript received February 20, 2017; revised May 2, 2017. This work was supported by the teaching reform program 'Research and Practice on the new mode of cultivating innovative talents of mechanical and electrical specialty’ of Jiangsu University (No. 2013JGYB025 \& No. 2013JGYB020).

Daohan Ge and Liqiang Zhang are with the Nano Science Technology, Jiangsu University Zhenjiang, China (e-mail: gedaohan@mail.ujs.edu.cn, zhanglq4158@ujs.edu.cn).

Fangwei Xie is with Mechanical and Electronic Engineering, Jiangsu university, Zhenjiang, China (e-mail: xiefangwei@ujs.edu.cn).

Pengfei Qian is with Mechanical Engineering, Jiangsu University Zhenjiang, China (e-mail: pengfeiqian@ujs.edu.cn). problems in the practice of bilingual teaching. Compared with the traditional mechanical processing technology, MEMS (micro-electro mechanical system) technology is a complex process, micro nano machining technology of complex 3D high integration features, it involves almost all modern processing technology, including lithography, epitaxy, thin film deposition, oxidation, diffusion, injection, sputtering, deposition, etching, dicing as the basic steps of the process and package [11].

Hence, the bilingual teaching of specialized course, such as MEMS, is very significant for teaching reform and personal training for students. In this paper, some difficulties and problems in bilingual teaching have been analyzed, and then, several benefit suggestions and strategies are put forward according to the authors' teaching experiences.

\section{Signification of BIlingual Teaching In Specialized COURSES}

Bilingual teaching is a kind of teaching mode that uses two languages to teach in the course of teaching [12]-[20]. In China, the general use of English as the second language as a tool and means of teaching, so that professional knowledge and learning of the second language can be carried out simultaneously. Bilingual teaching in specialized courses in colleges and universities, It is of great significance to improve the comprehensive quality of students and cultivate a large number of high-quality talents.

Firstly, the bilingual teaching mode of specialized courses is to integrate the professional English learning with the professional knowledge learning, which can carry on the specialized knowledge teaching at the same time, the active classroom atmosphere, and enhances the student to be able effectively to listen to, to say, to read, writes, each aspect English proficiency, and to develop the students' ability to communication skills in the cross-cultural context.

\section{Current Main Problems in the Bilingual Teaching IN SPECIALIZED COURSES}

\section{A. Teachers of Bilingual Teaching in Specialized Courses}

Teacher is the key factor in determining success or failure of teaching in colleges and universities [21]-[23]. High quality bilingual education to be implemented, there must be highly qualified bilingual teachers. Different with the general professional teachers, higher demands on teachers of bilingual teaching, teachers not only to master professional knowledge and skills, have some teaching experience, also has a considerable level of spoken English and the ability to 
use it correctly and appropriately in teaching. Due to the education environment, bilingual education started late in China, most teachers are non-English major teachers, level of foreign language teaching in general does not even have the ability to teach English and foreign language teachers are often not very proficient in professional knowledge, resulting in the current situation of the shortage of bilingual teachers in professional courses in colleges and universities in China, the uneven level of teaching and teaching effect less than ideal .

\section{B. Teaching Materials}

Teaching material is the most important carrier of teaching, to a certain extent the breadth and depth of influence teaching, bilingual education first selects the right materials [24]. Course content highly professional, is difficult in itself, if it is integrated into bilingual teaching, students will be more difficult to be understood, it is difficult to achieve the desired effect, so teaching materials in bilingual teaching of specialized courses is particularly important. Promotion of bilingual teaching in colleges and universities in our country, and not promulgated uniform textbooks currently used many bilingual textbooks for the school in university autonomy compilation or translation revision, lack scientific considerations and the reviser; students generally reflect the teaching content is obscure, severe blow to the enthusiasm of the students in the bilingual learning.

\section{Teaching Progress and Teaching Effect}

A big misunderstanding in the current bilingual teaching is that bilingual teaching is regarded as the English version of Chinese teaching. The development of professional courses bilingual teaching outlines and teaching tasks completely copy the teaching progress of Chinese teaching. Many students (especially those with poor English) are unable to understand the teaching content by taking into account the understanding of the complex English sentences and professional vocabularies in class, which reduces the teaching effectiveness [25]. There is an unavoidable contradiction between the progress of teaching and the teaching effect in this case, which may lead to the failure of both students to learn English and to learn professional knowledge. So, it is the main problem to be resolved that how to properly deal with their relationship.

\section{STRATEGIES AND PRACTICES FOR IMPROVING THE QUALITY OF BILINGUAL TEACHING IN MEMS COURSES}

MEMS devices are beginning to impact almost every area of science and technology. In fields as disparate as wireless communications, automotive design, entertainment, and light wave systems MEMS is increasingly becoming a key technology [26]. The MEMS course is one of the most important courses in Jiangsu University. In order to improve the bilingual teaching quality of MEMS course, some benefits methods and strategies has been put forward.

\section{A. Choose Appropriate Bilingual Teaching Materials}

Suitable teaching materials play a decisive role in the success of bilingual education, and an excellent English textbook, is the basis for successful implementation of bilingual teaching. I believe that the teaching materials of bilingual teaching in professional courses should try the best original foreign language teaching materials compiled by foreign experts. This kind of teaching materials are generally English language standard, and the overall structure is reasonable, illustrations, lively language, novel content, including the forefront of the discipline of science and technology dynamic. Compared with the domestic teaching materials, the original foreign textbooks not only includes the forefront of the latest development process and comprehensive content, but also pays much more attention to cultivating students to explore knowledge of thinking and self-learning ability for students to develop practical ability and creativity good guidance based on the student-oriented.

Take the "micro-electromechanical system" as an example, according to foreign teaching practice, our school chose foreign classic materials "Foundations of MEMS"; this textbook is written by Professor Chang Liu who is a famous expert in the field of micro-electromechanical system. The language in this textbook is easy to understand and not losing funny. The content involves comprehensive, rich examples, and detailed illustrations. All the After-school exercises are mostly open to explore questions, and help to inspire students thinking and cultivate their ability to explore innovation. More good news is that this material there are also Chinese version, can effectively resolve difficulties that may be encountered in students studying in bilingual reading, help students better study of professional knowledge.

\section{B. Strengthen the Training of Bilingual Teaching Teachers}

The key to the success of bilingual teaching reform in the specialty courses of colleges and universities is lacking of bilingual teachers. Only by enriching the teaching resources and improving the level of bilingual teaching can we improve the quality of bilingual teaching. First of all, the bilingual teaching of professional courses is more difficult compared with general courses. The school should create related learning, communication and learning opportunities encourage and support bilingual teachers' research and study out of school, improve teachers' ability of bilingual teaching. Secondly, give full play to the role of returned overseas teachers, encourage them to set up bilingual courses, and organize them to a backbone team and focus on their cultivation. Lastly, taking incentive mechanism, such as increasing the class fee of bilingual teaching, have prior claim on sending bilingual teachers to study abroad, step up the prize competition of bilingual teaching.

\section{Improve Teaching Methods}

Bilingual teaching is not equal to the Chinese teaching, and it requires teachers of teaching mode, curriculum content system, teaching method and teaching means of selection and design. Therefore, it is necessary to further improve the learning methods on the basis of learning and introducing foreign advanced teaching mode and content system.

\section{1) Bilingual teaching in English}

There are differences in thinking patterns between English and Chinese. The ultimate goal of bilingual teaching is to enable students to master the professional English, can read 
the professional English literature and communicate in a cross-cultural context. In order to achieve this goal, students need not only know the professional vocabulary, but also need to know how to communicate in English. Therefore, in bilingual teaching, we should cultivate the students' thinking transfer between English with Chinese, so as to deepen the understanding of the professional knowledge with the English thinking and logical habits. In this process, teachers should use the teaching method of gradual heuristic encouraging students to ask questions, simple and sequential induced, and need to pay attention to the teaching effect of after class consolidation.

In addition, some conceptions, definition, and technical term should be explained by English. Fox example, the information written on the blackboard in English; and then we must discussed by English when we introduce the concept and structures of the hot wire anemometer shown in Figure 1. We mark all parts in English logo and explain them, so that students master the professional knowledge while learning professional English.

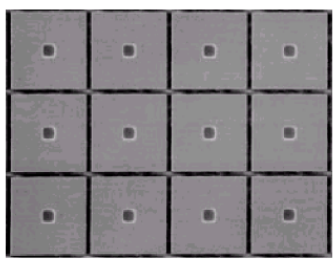

Top View of DMD

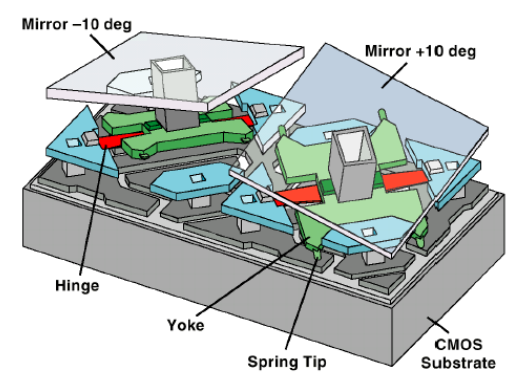

Fig. 1. The structure schematic diagram of hot wire anemometer.

\section{2) Using interactive heuristic teaching method}

In the class of bilingual teaching, Varies of interactive heuristic teaching methods should be applied intelligently to increase the interaction between teachers and students and strengthen the guidance of students as well as stimulate interest in learning. For example, at the beginning of each class, you can ask questions, to guide students to think, let the students start to listen to the question, which can enhance the purpose of students to attend lectures, to facilitate their understanding of the content of the class [24]. In the classroom teaching process, teachers can use more comprehensive case teaching task or project teaching, and situational simulation, to break the consistent model of "No communication in class", encourage students to participate in discussions with English, increase classroom interaction, arouses the enthusiasm of learning bilingual classes, with a large number of interactive discussion it is easier to improve students' English listening and speaking ability.

Especially for the MEMS course, which has a very wide range of applications, many interesting application cases (shown in Table I) can be discussed during the chapter of sensors and actuators. Moreover, teachers can encourage students to speculate on any potential usefulness of the technology or application of MEMS and present their finding to the class in English.

TABLE I: APPLICATION CASES OF MEMS

\begin{tabular}{lll}
\hline \hline No. & Application field & Application cases \\
\hline 1 & Biology, Pharmacy & Bioprobe, DNA sequencing chip \\
2 & Medicine & Endoscopic capsule, Electrical cochlear \\
3 & Aviation & Flow control, Microsatellite \\
4 & Optics & DMD \\
5 & Electronic & MEMS microphone, Tire pressure \\
6 & information & monitoring \\
7 & Military & Pressure sensor, Acceleration sensor \\
8 & Cultural animation & Fuze \\
\hline \hline
\end{tabular}

\section{3) Focus on after-class extension}

Language learning should not be confined to the classroom. The school should create more language learning environment for students, broaden the way for students to learn English, so that students can improve their ability of using English. Such as the creation of English corner, regular organization of English Salon activities, a large number of Libraries in the introduction of English original books, etc. It enables students to make full use of library resources and Internet resources to search and read related professional English literature, and helps students to understand the latest developments of their subjects, improve professional English reading and writing ability. These are the effective extension and supplement of bilingual teaching. As a bilingual teacher of "micro-electromechanical system", I regularly introduce the latest developments in the field of professional literature to my students, and guide students in extracurricular reading and classical literature translation, make students master professional knowledge and ability to improve the professional English level at the same time.

After class, open the MEMS system laboratory, guide students to visit, study, experiment, and further improve the understanding of the relevant knowledge, shown in Fig. 2.

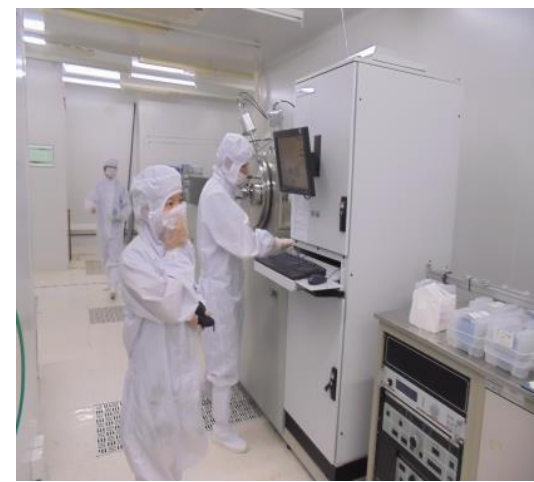

Fig. 2. Students visit and study in the MEMS laboratory.

\section{SUMMARY}

In conclusion, bilingual teaching is an important measure to improve the quality of teaching in Colleges and universities in China. At present, bilingual teaching in our country has just 
started, being in the stage of experimental reform, remaining many problems. As a university teacher, we should try to summarize the bilingual teaching mode and method suitable for our school according to the policy of the Ministry of education in order to improve the effect of bilingual teaching. In summary, the human department of universities should set some standards and strengthen the training of bilingual teaching teachers; and then, the specialized courses teachers should improve their bilingual teaching method and choose suitable foreign textbook.

\section{REFERENCES}

[1] J. J. Weber, "Review of O. Garcia. Bilingual education in the 21st century," Journal of Sociolinguistics, vol. 13, pp. 569-573, 2009.

[2] O. García and H. B. Beardsmore, "Bilingual education in the 21st century: a global perspective," Wiley-Blackwell, vol. 13, no. 4, pp. 469-472, 2009.

[3] O. García and C. E. Sylvan, "Pedagogies and practices in multilingual classrooms: Singularities in pluralities," The Modern Language Journal, vol. 95, no. 3, pp. 385-400, 2011.

[4] S. May and H. Richard, "Bilingual education in Aotearoa/New Zealand: At the crossroad," Bilingual and Multilingual Education, pp. 329-345, Jan. 2017.

[5] Y. B. Zhang, "On three-level bilingual teaching model for specialized course in universities," Foreign Language and Literature, vol. 27, no. 4, pp. 114-117, 2011.

[6] M. Deirdre, "Bilinguality and literacy: Principles and practice," International Journal of Bilingual Education and Bilingualism, vol. 12, no. 6, pp.731-734, 2009.

[7] C. J. Evans, "Literacy development in deaf students: case studies in bilingual teaching and learning," American Annals of the Deaf, vol. 149, no. 1, pp. 17-27, 2004.

[8] H. Marleen, "Teaching foreign languages: A challenge to ecuadorian bilingual intercultural education," International Journal of English Studies, vol. 9, no. 1, 2009.

[9] M. N. Carmen, "Western and indigenous knowledges in intercultural bilingual education in Ecuador," Alteridad: Revista de Educación, vol. 11, no. 2, pp. 206-220, 2016.

[10] Y. Solntseva-Nakova, "Main trands and prospects of bilingual education development," Obrazovanie i Nauka, vol. 1, no. 9, pp. 129-137, 2015.

[11] D. M. Marom, J. Talghader, and M. C. Lee, "Editorial special issue on optical MEMS and nanophotonics," IEEE Photonics Technology Letters, vol. 28, no. 5, pp. 547-549, 2016.

[12] L. M. Wang, X. M. Han, and M. Li, "Research on bilingual teaching of graduates for computer specialty in financial and economical colleges," International Journal of Modern Education and Computer Science, vol. 1, no. 1, pp. 53-59, 2009.

[13] Z. Z. Zhao and X. L. Zhang, "Research on practice teaching reform of mathematics specialty in local universities," Journal of Education in New Century, vol. 2, no. 1, pp. 12-15, 2014.

[14] A. Simsek, "Reform in the social sciences curriculum of Turkey: An evaluation in terms of teaching history," International Journal of Instruction, vol. 2, no. 2, pp. 73-90, 2009.

[15] R. Forman, "Using notions of scaffolding and intertextuality to understand the bilingual teaching of English in Thailand," Linguistics \& Education, vol. 19, no. 4, pp. 319-332, 2008.

[16] M. Schwartz, J. Kahn-Horwitz, and D. L. Share, "Orthographic learning and self-teaching in a bilingual and biliterate context," Journal of Experimental Child Psychology, vol. 117, no. 1, pp. 45-58, 2014.

[17] F. S. Baker, "The role of the bilingual teaching assistant: Alternative visions for bilingual support in the primary years," International Journal of Bilingual Education and Bilingualism, vol. 17, no. 3, pp. 225-271, 2014.

[18] C. Baker, "Foundations of bilingual education and bilingualism. Fifth Edition. Bilingual education \& bilingualism," Multilingual Matters, vol. 78, no. 3, pp. 390, Feb. 2011.

[19] Y. Y. Dai and H. Zheng, "A discussion about bilingual teaching in specialized courses and teaching in professional English," Higher Education Forum, no. 3, pp. 96-97, 2006.
[20] J. Allison, "Bilingual education and language policy in the global South," International Review of Education, vol. 60, no. 6, pp. 875-878, 2014.

[21] $\mathrm{Z}$. Xu, "The bilingual reform: a paradigm shift in foreign language teaching," International Journal of Bilingual Education and Bilingualism, vol. 17, no. 3, pp. 360-364, 2014.

[22] E. M. Weisman, "Teaching English language learners after proposition 227: Reflections of bilingual teachers," Issues in Teacher Education, vol. 11, pp. 53-68, 2002.

[23] S. Tom and E. E. García, "Education of limited english proficient students in California schools: An assessment of the influence of proposition 227 on selected teachers and classrooms," Bilingual Research Journal, vol. 24, no. 24, pp. 75-85, 2000

[24] L. Grant and D. Starks, "Screening appropriate teaching materials closings from textbooks and television soap operas," International Review of Applied Linguistics in Language Teaching, vol. 39, no. 1, pp. 39-50, 2001.

[25] A. Chin, "Impact of bilingual education on student achievement," Management Decision, vol. 42, no. 3-4, pp. 430-438, 2015.

[26] D. J. Bishop, C. R. Giles, and G. P. Austin, "The lucent LambdaRouter: MEMS technology of the future here today," IEEE Communications Magazine, vol. 40, no. 3, pp. 75-79, 2002.

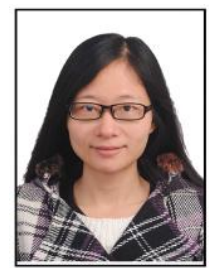

Daohan Ge was born in Yixing, Jiangsu province of China on Nov. 25, 1982. Now, she is an associate professor in the School of Mechanical Engineering of Jiangsu University. She received her B.Sc. degree in physics in 2005 from Nanjing University. She received her M.Sc. and Ph.D. degree in physics in 2010 from Chinese Academy of Sciences. Her research interests focus on the MEMS, nano science, and teaching \& reform of specialized courses. She is an author/coauthor for more than 20 articles in peer-reviewed international journals and conferences.

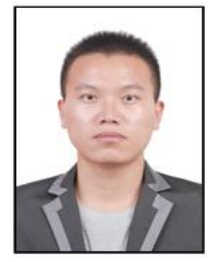

Liqiang Zhang was born in Anqiu, Shandong province of China on Jan. 6, 1984. Now, he is a lecturer in the School of Mechanical Engineering of Jiangsu University $\mathrm{He}$ received his B.Sc. degree and $\mathrm{M}$. Sc. degree in mechanical and electronic engineering from Guilin University of Electronic Technology, Guilin, China in 2006, and 2009 respectively. He received his Ph.D degree in mechanical and electronic engineering from School of Mechanical Engineering of Jiangsu University, Zhenjiang, China in 2012 His research interests focus on the integrity reliability of electronic packaging, interfacial heat transfer, CAD of micro/nano manufacturing, and teaching \& reform of specialized courses. He is an author/coauthor for more than 20 articles in peer-reviewed international journals and conferences.

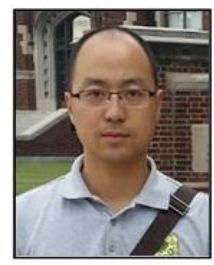

Fangwei Xie was born in Huaibei, PR. China on Jan. 6 1982. Now, he is associate professor in the School of Mechanical Engineering of Jiangsu University. He received his B.Sc. degree and Ph.D. degree in mechanical and electronic engineering from China University of Mining and Technology, Xuzhou, China in 2006, and 2010 respectively. $\mathrm{He}$ is a member of ASME. His research interests focus on hydraulic transmission and control, large electromechanical equipment speed start technology, hydraulic suspension system and vehicle type wind power generation equipment and energy storage technology, computational fluid dynamics -CFD theory and engineering application, hydromechatronics integrated system, and teaching \& reform of specialized courses. He is an author/coauthor for more than 30 articles in peer-reviewed international journals and conferences.

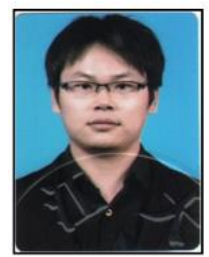

Pengfei Qian was born in Taizhou of PR. China on Jan. 6 , 1986. Now, he is a lecturer in the School of Mechanical Engineering of Jiangsu University. He received his B.Sc. degree and in mechanical and electronic engineering from Nanjing University of Science \& Technology, Guilin, China in 2009. He received his $\mathrm{Ph} . \mathrm{D}$. Degree in mechanical engineering from Zhejiang University, Hangzhou, China, in 2014 His research interests focus on the integrity reliability of electronic packaging, interfacial heat transfer, CAD of micro/nano manufacturing, and teaching \& reform of specialized courses. He is an author/coauthor for more than 15 articles in peer-reviewed international journals and conferences. 